\title{
Low class-switched memory B cells predict the need for continued immunoglobulin replacement following B cell reconstitution after rituximab: a case series and review of the literature
}

\author{
Caitlin M. G. McNulty ${ }^{1} \cdot$ Avni Y. Joshi $^{2}$ \\ Received: 29 July 2020 / Accepted: 22 September 2020 / Published online: 17 October 2020 \\ (C) Springer-Verlag GmbH Germany, part of Springer Nature 2020
}

\begin{abstract}
Background Rituximab is a chimeric monoclonal antibody that is used in a wide variety of conditions, ranging from nonHodgkin lymphoma to autoimmune diseases such as rheumatoid arthritis and multiple sclerosis. It causes depletion in B cells via antagonism of the CD20 receptor, which is important in initiating B cell cycles and differentiation. The function of CD20 is not entirely known, but it has been shown to be necessary for T-independent B cell immune responses. In some patients, hypogammaglobulinemia develops after rituximab treatment for unclear reasons.

Methods We present five cases of patients who received rituximab during their treatment for B cell lymphoma.

Results All of these patients presented with recurrent infections and hypogammaglobulinemia several years after completing chemotherapy, necessitating treatment with immunoglobulin replacement. B cell subset analysis revealed numeric B cell reconstitution; however, when these patients underwent B cell immunophenotyping, it revealed that the class-switched memory B cells (CSMB) (CD27+IgM-IgD-) remained significantly depressed.

Conclusion The low class-switched memory B cells (CD27+IgM- $\operatorname{IgD}-)$ may serve as a potential biomarker for the need of continued immunoglobulin replacement therapies.
\end{abstract}

Keywords Hypogammaglobulinemia $\cdot$ Rituximab

\section{Introduction}

Rituximab is a chimeric, anti-CD20 monoclonal antibody, commonly used and approved for use in rheumatoid arthritis, chronic lymphocytic leukemia, and non-Hodgkin Lymphoma and is also used off-label in a variety of autoimmune and malignant conditions [1-3]. CD20 is expressed on large pre-B cells, small pre-B cells, immature B cells, and mature B cells, including activated and memory B cells [4]. CD20 is down-regulated on plasma cells [4]. Rituximab's primary mechanism of action is by induction of antibody-mediated or complement-mediated cytotoxicity or via induction of apoptosis, which reduces the total number of circulating B cells [5].

Avni Y. Joshi

Joshi.avni@mayo.edu

1 St Paul Allergy and Asthma, 565 Snelling Ave South, St. Paul, MN 55116, USA

2 Division of Allergic Diseases, Mayo Clinic, 200 First St SW, Rochester, MN 55905, USA
Rituximab can be detected in the serum up to 9 months following infusion; B cell levels normalize back to pretreatment values approximately 1 year following infusion $[4,6]$.

However, the reconstituted B cells after rituximab therapy display an immature phenotype [6] with several studies showing defects in maturation with a decrease in memory B cells following treatment with rituximab [6-9]. Some patients develop hypogammaglobulinemia that requires ongoing immunoglobulin replacement to prevent severe infections. It is not known what precipitates prolonged hypogammaglobulinemia in some patients who have been treated with rituximab. To address this question, B lymphocyte immunophenotyping was obtained in 5 patients with hypogammaglobulinemia who had a history of B cell lymphoma and treated with rituximab.

\section{Methods}

Patients were seen in the Immunology Clinic at Mayo Clinic, Rochester, Minnesota, for further evaluation of hypogammaglobulinemia. All patients underwent 
quantification of T, B, and natural killer lymphocyte subsets by flow cytometry as part of standard work-up. In addition, the patients also underwent B lymphocyte subset immunophenotyping. The patients were all on replacement IgG therapy through the IV route (IVIG). A retrospective chart review was conducted for historical information.

The chart review study was conducted after IRB approval.

\section{Results}

\section{Case 1}

A 78-year-old woman was initially seen in 2012 for a diagnosis of hypogammaglobulinemia. She had a history of follicular lymphoma diagnosed in 2005 that was treated with 4 cycles of fludarabine, mitoxantrone, dexamethasone, and rituximab. She completed maintenance rituximab in 2007. Hypogammaglobulinemia to the immunoglobulin $\mathrm{G}$ ( $\operatorname{IgG}$ ) level of $375 \mathrm{mg} / \mathrm{dl}$ was noted in 2012 during the work up of bronchiectasis; her IgA value was $32 \mathrm{mg} / \mathrm{dl}$, and her IgM value was $13 \mathrm{mg} / \mathrm{dl}$ at that time. She was initiated on IVIG and has been evaluated in clinic on an annual basis. Her IgA values on in September of 2017 have declined to $12 \mathrm{mg} / \mathrm{dl}$, while her IgM value was $25 \mathrm{mg} / \mathrm{dl}$. Assessment of her B cells during that visit revealed a total CD19+ count of $189(15 \%)$ (normal 45-409 cells/mcL; 3-24\%) with $1.30 \%$ of CD19+ cells expressing CD27+ (normal 6.3-52.8\%). Her population of class-switched memory B cell (CD27+, M-D-) was $0.1 \%$ (normal 2.3-26.5\%).

\section{Case 2}

This 70-year-old man was diagnosed with follicular lymphoma in 2000. His chemotherapeutic regimens included chlorambucil, cyclophosphamide, prednisone, and cyclophosphamide, vincristine and prednisone (CVP), followed by $6 \mathrm{cy}-$ cles of cyclophosphamide, doxorubicin, vincristine and prednisone (CHOP) and 3 cycles of rituximab, dexamathasone, cytarabine and cisplatin (R-DHAP). He underwent a peripheral blood stem cell transplant in 2001. On recurrence of his cancer, he enrolled in a study where he received rituximab. Following this, he was treated with transmembrane activator and CAML-interactor fusion protein (TACI-Fc) followed by rituximab and concluded this treatment in 2008. After repeated sinus infections, his IgG level was assessed in 2015 and returned at $<7 \mathrm{mg} / \mathrm{dl}$. His IgM at that time was $147 \mathrm{mg} / \mathrm{dl}$, while his IgA was $<1 \mathrm{mg} / \mathrm{dl}$. He was started on IVIG supplementation and was seen in the Immunology clinic in May of 2017. B cell subsets obtained during that visit revealed total CD19+ cells of 641 (9\%) (normal 45-409 cells/mcL (324\%)) with CSMB cell count of $1.8(0.7 \%)$ (normal 7.061.0 cells/mcL; $2.3-26.5 \%)$.

\section{Case 3}

A 71-year-old man with a history of mantle cell lymphoma diagnosed in 2011 and treated with 6 cycles of rituximab, cyclophosphamide, doxorubicin, vincristine and prednisone (RCHOP) initially presented May 2016 with recurrent sinus infections. He was found to have an $\operatorname{IgG}$ value of $213 \mathrm{mg} / \mathrm{dl}$, with an IgM of $32 \mathrm{mg} / \mathrm{dl}$ and an undetectable IgA level. His CD19+ was 213 cells/mcL comprising $13.7 \%$ of the total population (normal 45-409 cells/mcL; 3-24\%). His number of CSMB cells was reduced at $0.7(0.4 \%)$ (normal 7.0-61.0 cells $/ \mathrm{mcL} ; 2.3-26.5 \%$ ). He was initiated on IgG replacement therapy and has been followed in the Immunology clinic on a bi-annual basis.

\section{Case 4}

A 60-year-old male presented with follicular lymphoma and was treated with rituximab in 2008. IVIG was started in 2015 with recurrent sino-pulmonary infections. Immune assessment showed severe pan hypogammaglobinemia and low classswitched memory B cells.

\section{Case 5}

A 44-year-old male presented to our clinic with hypogammaglobinemia. This patient had CVID diagnosed at age 30, started with replacement IgG therapy in 2004, and was diagnosed with diffuse large B cell lymphoma in 2011 and subsequent treatment with rituximab infusions.

He also had a history of autoimmune hemolytic anemia (AIHA). Immune assessment showed low IgA and IgM with normal IgG levels on supplemental IgG therapy.

Table 1 summarizes the clinical characteristics of these patients, and Table 2 describes the immunophenotyping of this cohort.

One patient was already on $\operatorname{IgG}$ therapy prior to rituximab use, and all the rest of the patients had hypogammaglobulinemia following treatment with rituximab for B cell lymphomas. We found a mean of 5.67 years between last rituximab dose and time of diagnosis of hypogammaglobulinemia. All of the patients exhibited adequate numeric $\mathrm{B}$ cell reconstitution with mean CD19+ cell counts by flow cytometry of 286 cells $/ \mathrm{mcL}$ (normal ranges 45-409 cells $/ \mathrm{mcL}$ ). Significantly, all patients exhibited a decrease in class-switched memory B cells (CD27+, M-, D-), with mean CSMB counts of 0.87 cells $/ \mathrm{mcL}$ (normal range 7.061.0 cells $/ \mathrm{mcL}$ ).

\section{Discussion}

Rituximab is a drug with utility in myriad of conditions. Prolonged hypogammaglobulinemia has been reported following treatment with rituximab, and some patients, such as 
Table 1 Clinical characteristics of the cohort

\begin{tabular}{|c|c|c|c|c|c|}
\hline & Patient 1 & Patient 2 & Patient 3 & Patient 4 & Patient 5 \\
\hline Gender & Female & Male & Male & Male & Male \\
\hline Age & 78 & 70 & 71 & 60 & 44 \\
\hline Malignancy & $\begin{array}{l}\text { Follicular } \\
\text { lymphoma }\end{array}$ & Follicular lymphoma & $\begin{array}{l}\text { Mantle cell } \\
\text { lymphoma }\end{array}$ & Follicular lymphoma & $\begin{array}{l}\text { Diffuse large B cell } \\
\text { lymphoma }\end{array}$ \\
\hline $\begin{array}{l}\text { Chemotherapeutic } \\
\text { regimen }\end{array}$ & $\begin{array}{l}4 \text { cycles } \\
\quad \text { fludarabine, } \\
\text { mitoxantrone, } \\
\text { rituximab } \\
\text { (2005), } \\
\text { maintenance } \\
\text { rituximab } \\
\text { completed } \\
2007\end{array}$ & $\begin{array}{l}6 \text { cycles fludarabine } \\
\text { and mitoxantrone } \\
(2002) ; 6 \text { cycles } \\
\text { unknown with } \\
\text { rituximab (2006), } \\
4 \text { cycles of unknown } \\
\text { regimen }(2010)\end{array}$ & $\begin{array}{l}6 \text { cycles } \\
\text { R-CHOP } \\
(2011)\end{array}$ & $\begin{array}{l}\text { Chlorambucil, cyclophosphamide, } \\
\text { prednisone, CVP followed } \\
\text { by } 6 \text { cycles CHOP, } 3 \text { cycles } \\
\text { rituximab DHAP, and } 4 \text { other } \\
\text { protocols, all of which contained } \\
\text { rituximab (2008) }\end{array}$ & R-CHOP (2011) \\
\hline $\begin{array}{l}\text { Date of last } \\
\text { anti-CD-20 } \\
\text { chemo }\end{array}$ & 2007 & 2010 & 2011 & 2008 & 2011 \\
\hline $\begin{array}{l}\text { Year IVIG } \\
\text { supplementation } \\
\text { initiated }\end{array}$ & 2012 & 2013 & 2016 & 2015 & 2004 \\
\hline $\begin{array}{l}\text { History of } \\
\text { recurrent } \\
\text { infections }\end{array}$ & Bronchiectasis & $\begin{array}{l}\text { Pneumonia, bronchiectasis, } \\
\text { sinus infections, shingles } \\
\times 2\end{array}$ & $\begin{array}{l}\text { Sinus } \\
\quad \text { infections }\end{array}$ & Sinus infections, pneumonia & $\begin{array}{l}* * \text { Diagnosed with } \\
\text { CVID age } 30 \text { on } \\
\text { IVIG }(2004)\end{array}$ \\
\hline $\begin{array}{l}\text { History of } \\
\text { autoimmunity }\end{array}$ & No & No & No & No & Yes AIHA \\
\hline
\end{tabular}

the patients presented here, require ongoing treatment with supplemental immunoglobulin to prevent infectious complications. It is unclear why only certain subsets of patients develop hypogammaglobinemia following rituximab therapy. It has been speculated that patients with prolonged hypogammaglobulinemia after rituximab use may in fact have baseline subclinical immune deficiency or dysfunction, including unrecognized common variable immune efficiency (CVID), which maybe unmasked or exacerbated by rituximab.

The etiology of prolonged hypogammaglobulinemia is unknown at this time. Certain factors may increase the risk for development of hypogammaglobulinemia, with duration of rituximab treatment and pretreatment IgG proposed as potential factors. However, the literature regarding possible risk factors is unclear. For example, in one study, pretreatment IgG values were correlated with risk; however; this was not shown in another study $[10,11]$. Similarly, one study found that $79 \%$ of patients requiring IVIG had received 2 or more courses of rituximab, while another study did not find this correlation [7, 10]. Malignancy further complicates our understanding of the development of hypogammaglobulinemia. Hypogammaglobulinemia that develops prior to any treatment has been known to occur in chronic lymphocytic leukemia [12].

The mechanism by which rituximab can cause hypogammaglobulinemia is also unclear. As discussed previously, in patients with lymphoma treated with rituximab,

Table 2 Immunophenotyping of the cohort

\begin{tabular}{|c|c|c|c|c|c|c|c|}
\hline Patient & $\operatorname{Ig} \mathrm{A}$ & $\mathrm{IgG}$ & $\operatorname{IgM}$ & CD19+ & $\begin{array}{l}\text { \%age of CD19+ cells } \\
\text { with CD27+ }\end{array}$ & $\mathrm{CD} 27+\mathrm{M}+\mathrm{D}+$ & $\begin{array}{l}\text { CD27+M-D- } \\
\text { (CSMB) }\end{array}$ \\
\hline $\begin{array}{l}\text { Normal } \\
\text { ranges }\end{array}$ & $61-356 \mathrm{mg} / \mathrm{dL}$ & $767-1590 \mathrm{mg} / \mathrm{dL}$ & $37-286 \mathrm{mg} / \mathrm{dL}$ & $\begin{array}{l}\text { 45-409 cells } / \mathrm{mcL} \\
\quad(3-24 \%)\end{array}$ & $6.3-52.8 \%$ & $\begin{array}{c}4.0-85 \text { cells } / \mathrm{mcL} \\
1.7-29.3 \%\end{array}$ & $\begin{array}{c}7.0-61.0 \text { cells } / \mathrm{mcL} \\
2.3-26.5 \%\end{array}$ \\
\hline 1 & 32 & 375 & 13 & $189(15 \%)$ & $1.30 \%$ & $1.3(1.0 \%)$ & $0.1(0.1 \%)$ \\
\hline 2 & 2 & 317 & 292 & $229(12 \%)$ & NA & NA & NA \\
\hline 3 & $<1$ & 282 & 32 & $213(13.7 \%)$ & $8.10 \%$ & $9.1(4.9 \%)$ & $0.7(0.4 \%)$ \\
\hline 4 & $<1$ & 7 & 147 & $402(27 \%)$ & $13.70 \%$ & $22.2(8.6 \%)$ & $1.8(0.7 \%)$ \\
\hline $5 *$ & 3 & $1050 *$ & 21 & $641(9 \%)$ & $0.9 \%$ & $2.5(0.6 \%)$ & $0.4(0.1 \%)$ \\
\hline
\end{tabular}

NA not available 
patients had an increase in naïve cells 1 year after infusion [6]. This decrease in memory cells was also seen in patients with lymphoma treated with stem cell transplant followed by rituximab adjuvant therapy [9]. In that study, 3 of the 4 patients lacked plasma cells on bone marrow biopsy [9]. This was noted in vitro in the B cells of a patient who developed hypogammaglobulinemia following treatment with rituximab for follicular lymphoma [8]. In this study, B cells stimulated with IL-6, IL-10, IL-15, and $B A F F$ failed to differentiate into plasma or memory B cells [8].

\section{Conclusions}

Here, we present 5 cases of patients with decreased CSMB cells despite adequate numeric $\mathrm{B}$ cell reconstitution. The interplay between rituximab, malignancy, and B cell reconstitution is complex, and the mechanisms of this process remain elusive. A limitation of this report is the limited number of patients assessed; however, this report and other studies have demonstrated that there is a decrease in CSMB in patients with prolonged hypogammaglobulinemia following rituximab [7-9]. These cases serve as an important reminder to check for IgG dysfunction in patients who have recurrent infections and have a history of rituximab and may suggest a role for assessment of CSMB to predict the need for IVIG replacement in this cohort.

\section{Compliance with ethical standards}

Conflict of interest The authors declare that they have no conflict of interest.

\section{References}

1. FDA (1997) Rituximab (Rituxan) product information. FDA Open access Doc 2(1):1-35

2. Davis BTA, White CA, Link B, Maloney DG, Dillman RO, Williams ME et al (1999) Single-agent monoclonal antibody efficacy in bulky non-Hodgkin's lymphoma: results of a phase II trial of rituximab. J Clin Oncol 17(6):1851-1857

3. Randall KL (2016) Rituximab in autoimmune diseases. Aust Prescr 39(4):131-134

4. Pescovitz MD (2006) Rituximab, an anti-CD20 monoclonal antibody: History and mechanism of action. Am J Transplant 6(5 I): 859-866

5. Taylor RP, Lindorfer MA (2007) Drug insight: the mechanism of action of rituximab in autoimmune disease - the immune complex decoy hypothesis. Nat Clin Pract Rheumatol 3(2):86-95

6. Anolik JH, Friedberg JW, Zheng B, Barnard J, Owen T, Cushing E et al (2007) B cell reconstitution after rituximab treatment of lymphoma recapitulates B cell ontogeny. Clin Immunol

7. Kaplan B, Kopyltsova Y, Khokhar A, Lam F, Bonagura V (2014) Rituximab and immune deficiency: case series and review of the literature. J Allergy Clin Immunol Pract 2(5):594-600. [Internet]. Available from. https://doi.org/10.1016/j.jaip.2014.06.003

8. Irie E, Shirota Y, Suzuki C, Tajima Y, Ishizawa K, Kameoka J, Harigae H, Ishii T (2010) Severe hypogammaglobulinemia persisting for 6 years after treatment with rituximab combined chemotherapy due to arrest of B lymphocyte differentiation together with alteration of $\mathrm{T}$ lymphocyte homeostasis. Int J Hematol 91: 501-508

9. Nishio M, Fujimoto K, Yamamoto S, Endo T, Sakai T, Obara M, Kumano K, Minauchi K, Yamaguchi K, Takeda Y, Sato N, Koizumi K, Mukai M, Koike T (2006) Hypogammaglobulinemia with a selective delayed recovery in memory B cells and an impaired isotype expression after rituximab administration as an adjuvant to autologous stem cell transplantation for non-Hodgkin lymphoma. Eur J Haematol 77(3):226-232

10. Casulo C, Maragulia J, Zelenetz AD (2014) Incidence of hypogammaglobulinemia in patients receiving rituximab and the use of intravenous immunoglobulin for recurrent infections. Clin Lymphoma Myeloma Leuk 13(2):106-111

11. Kado R, Sanders G, McCune WJ (2017) Diagnostic and therapeutic considerations in patients with hypogammaglobulinemia after rituximab therapy. Curr Opin Rheumatol 29(3):228-233

12. Parikh SA, Leis JF, Chaffee KG, Call TG, Hanson CA, Ding W, Chanan-Khan AA, Bowen D, Conte M, Schwager S, Slager SL, van Dyke DL, Jelinek DF, Kay NE, Shanafelt TD (2015) Hypogammaglobulinemia in newly diagnosed chronic lymphocytic leukemia: natural history, clinical correlates, and outcomes. Cancer. 121(17):2883-2891

Publisher's note Springer Nature remains neutral with regard to jurisdictional claims in published maps and institutional affiliations. 